that the graysquirrel population in the palmy days of 1800 may easily have numbered several billions.

These great movements have never been clearly observed. The only way at present possible to fill the gap is by collecting the testimony of eyewitnesses - the old-timers who are passing away-for I have little faith in any great emigration since 1870 . That was about the latest date at which primitive conditions continued anywhere in the northern Mississippi Valley.

Will not our young naturalists render service now by interviewing all available old-timers - the men who joined in the squirrel hunts of the '60's - and make as full a record as possible of the time, place, extent, direction, etc., of every emigration that can be traced, together with facts that bear upon its cause and results or that in any way offer interesting light?

\title{
AN APPARENT EFFECT OF WINTER INACTIVITY UPON DISTRIBUTION OF MAMMALS
}

By Hartley H. T. Jackson

INTRODUCTION

It was the writer's pleasure during the past summer (1919) to spend a few weeks investigating the terrestrial vertebrate fauna of the Apostle Islands, Wisconsin, as a part of the general study of the land vertebrates of the state now being undertaken by the United States Biological Survey, the Wisconsin Geological and Natural History Survey coöperating. My first visit to the islands was from June 22 to 26, when all the time was spent on Madeline Island. I again visited the islands July 3 to 24, accompanied by Mr. Harry H. Sheldon and Mr. Arthur $\mathrm{J}$. Poole who assisted in the work. On this second visit careful investigations were made on Madeline Island, July 3 and 4, 12 to 15, 20 and 21; Outer Island, July 5 to 11; Presque Isle or Stockton Island, July 15 and 16; Gull Island, July 18; Little Manitou Island or Gull Rock, July 18; Michigan Island, July 18; and Sand Island, July 23. Observations of a more or less superficial nature were also made on other islands, but physiographical conditions were such that the more intensive work on the islands selected undoubtedly gave us a fairly accurate idea of the mammalian fauna of the islands as a whole. Mr. Sheldon and Mr. Poole returned to the islands September 4 and remained until 


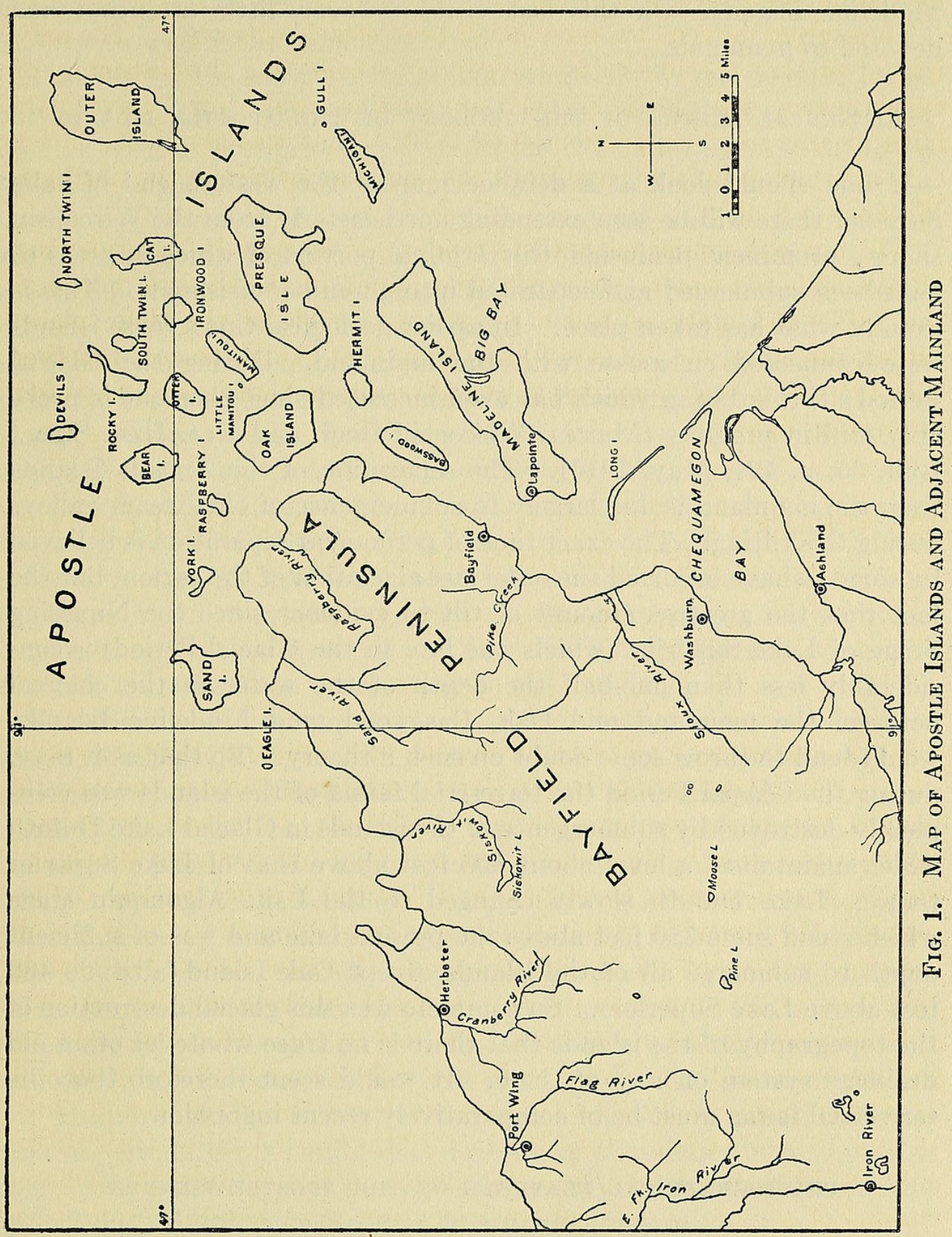


September 19, spending the greater part of their time on Outer and Madeline Islands. On this last visit, however, little attention was devoted to mammals.

HISTORICAL SKETCH OF THE GEOLOGY OF THE APOSTLE ISLANDS

If one should look at a detailed map of the western end of Lake Superior there will be seen extending northeasterly from the Wisconsin shore a prominent peninsula, the terminal portion of which appears to have been submerged and separated into a number of islands. This is exactly what has taken place. In earlier geological times these islands were connected en masse with the mainland. During the Glacial Period a tilting began which has even increased since then and is probably still in progress (Martin, Wisconsin Geol. and Nat. Hist. Surv., Bull. 36, p. 424, May, 1916). The separation of the Apostle Islands from the mainland is due largely to submergence of old stream valleys during this tilting. The exact time of permanent separation is believed by some to have occurred since the last glaciation of the region, but the fact that the greatest amount of tilt in evidence since the Nipissing Stage of Lake Superior (which was late in the Glacial Period) is considerably less than one-half the depth of the water in the channel between the mainland and Oak, Basswood, and Madeline Islands, would tend to throw some doubt on such a theory. Be that as it may, during the Glacial Period the terrestrial fauna of the islands was completely destroyed by submergence of the islands in Glacial Lake Duluth which maintained a level about 500 feet above that of Lake Superior today. Lake Duluth slowly changed to the Lake Algonquin stage which stood some 350 feet above the present lake and was of sufficient depth to submerge all of the islands except Oak Island (altitude 480 feet above Lake Superior). So complete was this glacial destruction of the topography of the islands that there is no trace whatever of an old drainage system on any of them. It would seem therefore that the terrestrial fauna must be of comparatively recent ingression.

\section{PHYSIOGRAPHICAL FEATURES OF THE APOSTLE ISLANDS}

Turning now to the present, we find the islands 23 in number and varying in size from Madeline Island which is over 12 miles long and nearly 3 wide, to Little Manitou Island (or Gull Rock) which is only 300 feet long and 30 feet broad basally, narrowing to about 5 feet in 
width at the summit. Little Manitou Island will soon meet the fate of Steamboat Island which has entirely disappeared by action of wind and waves within the memory of man.

There is for the most part a general similarity in the topography of the islands. The east and northeast sides generally rise from the water's edge in precipitous red sandstone cliffs varying from 10 to 80 feet high, usually 10 to 30 feet. Sandy beaches are most likely to be on the southwestern shores. Northern, western, and southern slopes are frequently steep clay-banks. A few more or less intermittent small creeks offer some surface drainage, but most of the precipitation washes directly down the banks into the lake. There are a few sloughs surrounded by marshes and bogs on some of the islands, the largest being near Big Bay on the southeastern side of Madeline Island midway its length. Other sloughs of considerable size are near the southwestern corner of Outer Island, and near the base of Presque Isle Point towards the eastern end of Presque Isle. Each of these sloughs has been formed by a separation of a body of the lake by sand beaches. The inland sides of the sloughs tend to be more boggy than the outer sides. These bogs contain a vegetation typical of sphagnum-cassandra bogs, the tamarack and spruce growth being limited. They differ in no essential features from the same type of bog on the mainland.

The islands are covered with a Canadian Zone vegetation which on Outer, Michigan, Cat, and a few other islands has been undisturbed by civilization but on others has been more or less destroyed by lumbermen. Spruces (Picea canadensis and mariana), balsam fir (Abies balsamea), pines (Pinus strobus, resinosa and divaricata), arbor vitæ (Thuja occidentalis), hemlock (Tsuga canadensis), ground hemlock (Taxus minor), mountain maple (Acer spicatum), mountain ash (Sorbus americana), birches (Betula papyrifera, lenta and lutea), and aspens (Populus tremuloides) constitute a greater portion of the vegetation, while around the bogs and sloughs is found a growth of alders and willows. In all ecological features the islands offer an environment for mammals similar to that of the mainland and on casual observation one would think conditions ideal for an abundance of mammalian life. As a matter of fact mammals are poorly represented in number of individuals and, even more so, in number of species. 
MAMMALIAN FAUNA OF THE APOSTLE ISLANDS COMPARED WITH THAT OF THE MAINLAND

A comparison of the mammalian fauna of the Apostle Islands with that of the Wisconsin shore of Lake Superior reveals some interesting factors in distribution. A careful study of the mammals of the islands with intensive collecting for the smaller ones resulted in our obtaining records of only 18 species. Specimens were secured of the red squirrel (Sciurus hudsonicus), Canadian white-footed mouse (Peromyscus maniculatus gracilis), red-backed mouse (Evotomys gapperi gapperi), meadow mouse (Microtus pennsylvanicus pennsylvanicus), coyote (Canis latrans latrans), masked shrew (Sorex personatus personatus), and short-tailed shrew (Blarina brevicauda). Three others, Minnesota varying hare (Lepus americanus phoonotus), hoary bat (Nycteris cinereus), and a small bat (Myotis sp.) were seen by members of our party, the hare several times. Tracks were seen of the muskrat (Fiber zibethicus zibethicus) and the red fox (Vulpes fulvus fulvus). Reliable reports from residents of the islands show the presence of northern white-tailed deer (Odocoileus virginianus borealis), wharf rat (Rattus norvegicus), house mouse (Mus musculus musculus), otter (Lutra canadensis), a weasel (from descriptions probably Mustela cicognanii), and the Minnesota mink (Mustela vison letifera).

One who is familiar with the habits of mammals will notice that with the exception of the bats these are all mammals that are more or less active in winter. Bats probably ingressed the islands by flight in the summer season. The wharf rat and the house mouse were probably introduced in freight shipments. Others, such as the red squirrel, muskrat, otter, mink, and possibly the deer, may at times have swum from the mainland to the islands. However, except the aquatic mammals, the bats, the wharf rat and house mouse, the mammals known to inhabit the islands resolve themselves into two categories: namely, (A) those that are active in winter and wander considerable distances at such times, and (B) those that are more or less active in winter and are frequently found among driftwood and logs near the beach.

The mammals that travel considerable distances during the winter include the deer, red squirrel, varying hare, red fox, coyote, and weasel. Inquiry of residents of the islands and Bayfield disclosed the fact that each of these animals has at times been seen on the ice. Definite statements of deer, varying hares, a red fox (silver phase), and coyotes 
having been shot on the ice were given. The minimum distance between the mainland and the nearer islands is approximately $1 \frac{1}{2}$ miles, which would by no means be excessive even for some of the smaller mammals.

Into the second category (B), those mammals which are active in winter and frequently found among logs and driftwood near the beach, fall the Canadian white-footed mouse, red-backed mouse, meadow mouse, masked shrew, and short-tailed shrew. These mammals were probably carried to the islands on driftwood, particularly with the ice floes and jams.in the spring. The power of these floes to carry debris and vegetation can be appreciated only by one who has seen the results of the impacts of this ice along the shores of the islands.

Turning now to the mammals of the mainland as represented by observations made at Bayfield, and collections and observations made at Herbster and Orienta, Wisconsin, we find present all of the species of mammals found on the islands and in addition the following relatively common: gray chipmunk (Tamias striatus griseus), little striped chipmunk (Eutamias borealis neglectus), striped ground-squirrel (Citellus tridecemlineatus tridecemlineatus), Canada woodchuck (Marmota monax canadensis), jumping mouse (Zapus hudsonius hudsonius), porcupine (Erethizon dorsatum), Mearns cottontail rabbit (Sylvilagus floridanus mearnsi), Minnesota skunk (Mephitis mephitis minnesoto), and the black bear (Ursus americanus americanus). A glance at this list and we note that with the exception of the cottontail all of these mammals are inactive in winter. The cottontail has only recently ingressed the region, having made its first appearance near Bayfield within the last ten years. The same applies to the striped ground-squirrel. Of the other mammals not found on the islands the gray chipmunk, little striped chipmunk, Canada woodchuck, jumping mouse, and black bear are known to hibernate; the skunk, while not in a true state of hibernation, remains in a state of lethargy during the winter in a den in the ground; and the porcupine at this season is inactive, spending weeks at a time in the top of a single tree or in a hollow log in the forest. The hibernating mammals spend their dormant periods in nests in the ground and are well protected from the effects of ice erosion which takes place in the early spring. The point of course can be raised that only negative evidence is supplied as proof of the absence of these mammals on the islands. But this negative evidence is so strong that it is fairly conclusive. Special effort with approved means of collecting was made to obtain each of these species on the islands. Methods of calling chipmunks, ground squirrels, and woodchuck which never 
failed on the mainland were futile here. Moreover old-time residents of the islands, men who were familiar with outdoor life, repeatedly told me that chipmunks, "gophers" (ground squirrels), woodchucks, porcupines, skunks, and bears were not found on the islands. One of the islands is called "Bear Island" but I could find no evidence that a bear had ever been seen on that or any other island of the group. It is said that a few cottontail rabbits have been seen at Lapointe, but I was unable to secure verification of their presence there. In view of the habits of this mammal its occurrence on the islands may be expected.

\section{CONCLUSION}

It can be seen from these remarks that the mammals known to inhabit the Apostle Islands are all more or less active during the winter, while those inhabiting the adjacent mainland and not known from the islands tend to be inactive in winter. Bearing in mind that the terrestrial biota of these islands is, geologically speaking, very recent and has been derived from the mainland, it is strongly suggested that this winter inactivity has had an influence on the distribution of certain mammals by tending to prevent them from crossing on the ice and keeping them out of the debris carried from the beaches by the ice floes. While present evidence indicates complete isolation of mammals inactive in winter from the islands, it would seem that this restriction would retard ingression of these mammals onto the islands rather than completely inhibit it. 


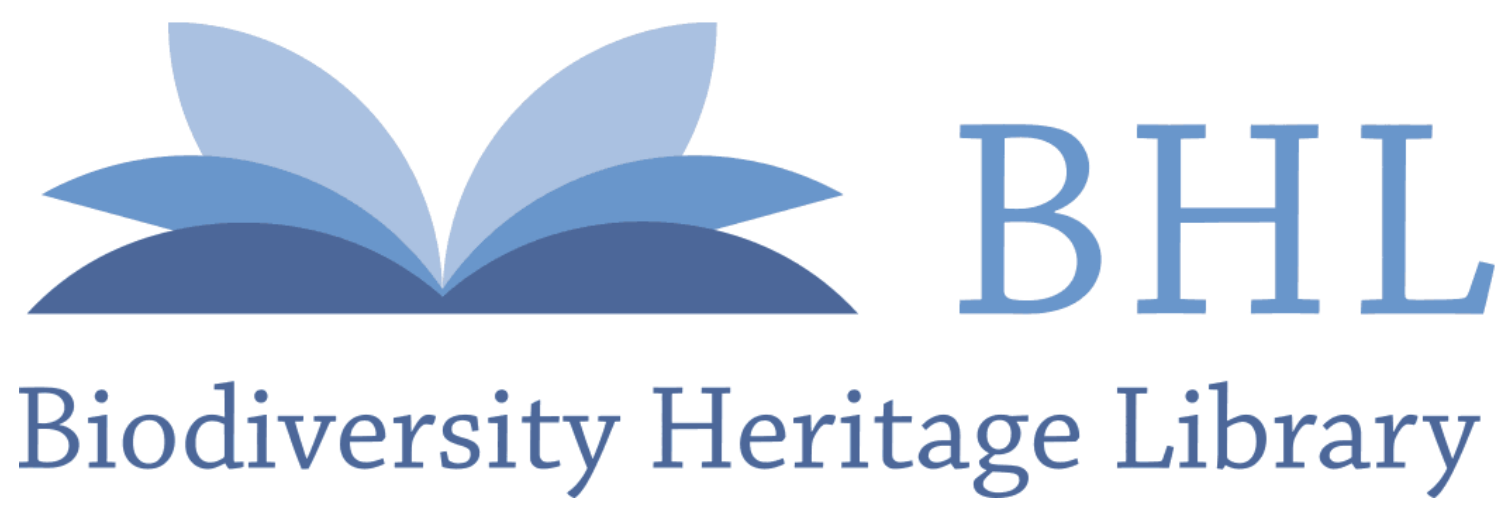

1920. "An Apparent Effect of Winter Inactivity upon Distribution of Mammals." Journal of mammalogy 1, 58-64. https://doi.org/10.2307/1373741.

View This Item Online: https://www.biodiversitylibrary.org/item/220052

DOI: https://doi.org/10.2307/1373741

Permalink: https://www.biodiversitylibrary.org/partpdf/90484

\section{Holding Institution}

Smithsonian Libraries

\section{Sponsored by}

Biodiversity Heritage Library

\section{Copyright \& Reuse}

Copyright Status: Not in copyright. The BHL knows of no copyright restrictions on this item.

This document was created from content at the Biodiversity Heritage Library, the world's largest open access digital library for biodiversity literature and archives. Visit BHL at https://www.biodiversitylibrary.org. 